\title{
Teacher Effectiveness in Relation to Type of Institution, Emotional Intelligence and Teaching Experience
}

\author{
Amit Kauts \\ MGN College of Education, India \\ amitkauts@yahoo.com
}

\author{
Vijay Kumar Chechi \\ Lovely Professional University, India \\ vijay.chechi@1pu.co.in
}

\begin{abstract}
Present study aims at studying the influence of the emotional intelligence, age and qualification on the teacher effectiveness of the teachers. The study population included secondary schools teachers working in Jalandhar and Ludhiana districts of Punjab, India. Using a multi-stage random sampling method, a sample volume of 739 teachers was determined. Two main instruments were used to measure the study variables: a 80-item questionnaire by C R Darolia on emotional intelligence (five scales: Self-awareness, Motivating Oneself, Managing Emotions, Empathy and Handling Relations, and a 60item Teacher Effectiveness Scale by Kumar and Mutha, 1985. The frequency, mean and standard deviation values were calculated and a 3 way ANOVA analysis was performed to evaluate the statistical significance of the findings. The study results revealed that: (a) Differences in teacher effectiveness of groups of teachers' based on school type i.e. government and private secondary schools, are not significant. (b) Teachers with low emotional intelligence are less effective in teaching than teachers with high emotional intelligence. c) More experienced teachers are found to be more effective than less experienced teachers. Thus, it can be concluded that emotional intelligence and teaching experience matters in making of a teacher to be effective.
\end{abstract}

Keywords: Emotional intelligence, teacher effectiveness, age, qualification and school type. 


\section{Introduction}

'If we want to help people learn, we must expect to encounter emotion, and we must take it seriously.'

James Zull

The Indian Education Commission (1966) keeping this in consideration to enjoin education with growth, in its report titled 'Education and National Development' gave importance to the education. The report says, "In a world based on science and technology, it is education that determines the level of prosperity, welfare and security of the people. On the quality and number of people passing out of our schools and colleges will depend on our success in the great enterprise of national reconstruction whose principle objective is to raise the standard of living of our people".

The success of education system depends a lot on the teacher. Therefore, a growing number of education reformers, policymakers, and researchers have argued that the importance of teachers' role in the development of wholesome personality of the child at the elementary and secondary level. These proponents pointed out measures to increase the teacher effectiveness through, for example, good salary, say in the operation of schools, increase of opportunities to improve their teaching skills, providing support or assistance, and proper rewards or recognition for their efforts. The rationale underlying this view is that upgrading the teaching occupation will lead to improvements in the motivation and commitment of teachers, which, in turn, will lead to improvements in teachers' performance, which will ultimately lead to improvements in student learning (Carnegie Forum 1986; Darling-Hammond 1984; Rosenholtz 1989; Sergiovanni and Moore 1989; Weis et al. 1989; Conley and Cooper 1991; Holmes Group 1986; Darling-Hammond 1995; Talbert and McLaughlin 1993). This interest in the professionalization of teaching has gained recognition and impetus from a number of quarters. 
Teacher effectiveness is determined by a number of factors like certification, students' ratings, experience, teacher preparation programs and degrees, teacher coursework and teacher's own test scores. Cross and Rigden (2002) describes actions necessary to improve teacher quality i.e. by deepening teachers' content knowledge and strengthening candidates' experiences in schools, hiring qualified teachers, and supporting teacher learning. Similarly, Analysing effectiveness of teachers, Decker, et. al. (2004) using data from 17 schools indicated that, on average, students of TFA teachers raised their mathematics test scores (on the Iowa Basic Skills test) 0.15 standard deviation above students of comparison certified teachers.

Onderi and Croll (2009) conducted a study of the perceptions of teachers in secondary schools in the Gucha district of Kenya of their own effectiveness, and reported that three dimensions of selfperceived effectiveness i.e. pedagogic process, personal and affective aspects of teaching and effectiveness are instrumental in pupil performance. Teachers tended to rate themselves relatively highly with regard to the first two, process-oriented, dimensions but less highly on the third, outcome-oriented, dimension. Self-ratings for pupil outcomes correlated with pupil examination performance at school level.

Similarly teachers' effectiveness can be improved by keeping the size of the classroom small. In smaller classes, there is more individualized teacher support for learning. Teachers from all grade levels said that reduced class size increased student learning and enhanced their teaching effectiveness, whereas large classes had the opposite effect (Blatchford, Moriarty, Edmonds and Martin,2002; Reynolds, Reagin, and Reinshuttle, 2001).

In a school situation the teachers is expected to perform different roles. Some teachers perform one or two roles, but most of them does most of the roles. For example a teacher in a school is expected to perform following roles of information provider, facilitator, assessor, planner, resource 
developer and the most important the role model. With such an expectation from a teacher, teaching becomes a stressful profession. Research findings suggest that unrealistic expectations between teacher training and reality of teaching, a lack of clear performance standards with constructive feedback, increasing physical demands and added responsibilities, inadequate pay and resources, and physically and psychologically dangerous work environments lead to teacher dissatisfaction and attrition. While teachers cannot control these issues, but, they can learn and choose to develop skilled behaviors to deal with stressors.

Understanding this along with the variety of roles to be played by the teacher in the school makes to think the need to recognise emotional component of the teaching-learning exchange and to be able to work with it. In other words, teachers need to use emotional intelligence in order to assist others to learn. And this will in turn prove their teaching effectiveness.

Recent research in the area of emotional intelligence conclude that social and emotional skills are associated with success in many areas of life, including effective teaching, student learning, quality relationships, and academic performance (Mayer, Salovey, \& Caruso, 2004b; Sutton \& Wheatley, 2003). Similarly, intrapersonal emotional intelligence and interpersonal emotional intelligence were found to predict significantly active coping strategy, but teacher self-efficacy did not contribute independently to the prediction of active coping (Chan, 2008). Emotional intelligence was found to be helpful in reducing occupational stress of teachers and enhancing their effectiveness in teaching (Kauts and Saroj, 2010).

Teacher's effectiveness among primary school teachers of government \& private schools; male $\&$ female teachers is found to be equal. However, significant difference in the level of teacher effectiveness of urban \& rural primary school teacher (Singh, 2012). Similarly, in another study on secondary school Male and Female teachers, Govt. and Private school Teachers' were found 
equally effective in teaching but urban teachers were found more effective than rural teachers (Singh, 2012). Hoghlighting the importance of effective teachers, Kalita (2012) reported that effective teachers create an effective climate in the classroom to provide security to children, creating favourable situations for affective, cognitive and psychomotor development of pupils, helping in fostering readiness for social interactions and perform other manifold activities; Female teachers are more effective than male teachers in secondary schools; Graduate teachers are equally effective as Post graduate teachers; and, Teaching experience / training has no significant impact on teachers effectiveness. Manu and Yellappa (2013) showed that female and government secondary school teachers have higher teaching effectiveness. Rural and more experience secondary school teachers have higher teaching aptitude. Graduate and post graduate teachers are equally effective teachers.

A number of National Center for Analysis of Longitudinal Data in Education Research (CALDER) studies confirm findings from existing research that, on average, brand new teachers are less effective than those with some experience under their belts (Clotfelter, Ladd, and Vigdor 2007a, 2007b; Harris and Sass 2007; Kane, Rockoff, and Staiger 2006; Ladd 2008).

In Ling's study (as cited in Salamuddin, Harun, \& Abdullah, 2011) on residential schools explored teacher effectiveness in implementing extra-curricular activities found that experienced teachers are far more effective in implementing extra-curricular activities than are teachers with less teaching experience.

In Basiron's study (as cited in Salamuddin, Harun, \& Abdullah, 2011) on management of Extracurricular programs among secondary schools, it is concluded that more experienced teachers have less problems in managing sports and games in secondary schools as compared to less experienced teachers. 


\section{Statement of the Problem}

The present study is entitled as Teacher Effectiveness in Relation to Emotional Intelligence, Type of Institution and Teaching experience among Secondary School Teachers. It explored the significant difference for teacher effectiveness among high and low emotionally intelligent secondary school teachers with different teaching experience and working in the state of Punjab.

\section{Significance of the Problem}

Teachers are expected to fill many roles in their daily tasks. These roles may include assessor, planner, curriculum developer, information provider, role model, facilitator, and resource developer. As a result of balancing these many roles, teachers' efficiency matters a lot. With so much of things to handle in situation the teachers seem to have strong emotional intelligence. As pointed that teaching job is preferred by persons with high emotional intelligence (Caruso, Mayer and Salovey, 2002) and individuals with High EI can better perceive emotions, use them in thought, understand their meanings, and manage emotions better than others. Solving emotional problems likely requires less cognitive effort for this individual. The person also tends to be higher on verbal, social and other intelligences (Mayer, Salovey and Caruso, 2004b). Thus, the present study intends to find out the role of emotional intelligence, school type and teaching experience on the teacher effectiveness of the teachers.

\section{Delimitations of the Study}

The study is delimited to the teachers working in secondary schools in Jalandhar and Ludhiana districts of Punjab.

\section{Objectives of the Study}

The present study is designed to study teacher effectiveness in relation to Emotional Intelligence, type of institution and teaching experience of teachers working in secondary schools. 


\section{Hypotheses}

The following hypotheses have been framed keeping in view the above said objective:

1. There is no significant difference in the teacher effectiveness of secondary school teachers in relation to their emotional intelligence.

2. There is no significant difference in the teacher effectiveness of secondary school teachers in relation to their type of institution.

3. There is no significant difference in the teacher effectiveness of secondary school teachers in relation to their teaching experience.

4. There is no interaction effect of school type and emotional intelligence, school type and teaching experience, \& emotional intelligence and teaching experience on the scores of Teacher effectiveness of secondary school teachers.

5. There is no interaction effect of type of institution, teaching experience and emotional intelligence on the scores of teacher effectiveness of teachers working in secondary schools.

\section{Methodology}

\section{Sample}

In the present study, 30 schools comparable in terms of infrastructure, faculty and student strength each were selected randomly from two clusters i.e. Jalandhar and Ludhiana districts of Punjab. Thus, 739 secondary school teachers were selected from two clusters i.e. Jalandhar and Ludhiana districts of Punjab. Emotional intelligence questionnaire was administered to all these secondary school teachers. The scores obtained through emotional intelligence questionnaire were arranged in ascending order. On the scores of emotional intelligence 30\% top and 30\% bottom school teachers were identified as teachers with low and high emotional intelligence. In the second phase, 
the selected secondary school teachers were asked to fill Teacher effectiveness scale for further investigation.

\section{Prodecure}

The investigator took 2 districts out of 17 disctricts of Punjab because of the time resources and effort required. More or less the districts are representative of population of Punjab in other districts as the recruitment policies, environment and working conditions and also the cultural background are similar among the sample population. The sample is representative in nature of universe population of teachers working in secondary schools of Punjab. In the present study, 30 schools (15 government and 15 private secondary schools) comparable in terms of infrastructure, faculty and student strength each were selected randomly from two clusters i.e. Jalandhar and Ludhiana districts of Punjab. 20 teachers from each school were selected randomly from the available teachers. Thus, 600 secondary school teachers each were selected from two clusters i.e. Jalandhar and Ludhiana districts of Punjab. Initially, 1200 secondary school teachers comprised the sample of the study. Out of them, 739 (61.58\%) secondary school teachers agreed to be part of the study and completed the exercise for final calculation of data from the two clusters i.e. Jalandhar and Ludhiana districts of Punjab. Out of them, 342 are from government schools and 397 are from private schools respectively. Emotional intelligence questionnaire was administered to all these secondary school teachers. The scores obtained through emotional intelligence questionnaire were arranged in ascending order. On the scores of emotional intelligence $30 \%$ top and $30 \%$ bottom school teachers are identified as teachers with low and high emotional intelligence from government and private schools. In the second phase, the selected secondary school teachers were asked to fill Teacher effectiveness scale for further investigation. The collected data was tabulated and subjected to statistical analysis and interpretation as per the hypotheses. 


\section{Tools}

The following tools were used for data collection:

1. Multidimensional Measures of Emotional Intelligence (MMEI) by C. R Darolia, 2003.

2. Teacher Effectiveness Scale (TES) by Kumar and Mutha, 1985.

\section{Statistical Techniques}

The following statistical techniques were employed to analyze the data:

1. Means and standard deviations were employed to understand the nature of data on the scores of teacher effectiveness.

2. 3 way ANOVA was employed to find significant difference between various sub groups of high and low emotionally intelligent secondary school teachers working in government and private schools with different teaching experience.

\section{Research Design}

$2 \times 2 \times 2$ factorial design was employed on the scores of teacher effectiveness wherein, type of institution, teaching experience and emotional intelligence were studied as independent variables and were used for the purpose of classification viz. high and low emotional intelligence, less experienced and more experienced \& government and private schools. Teacher Effectiveness was studied as dependent variable.

\section{Analysis and Interpretation}

To study the teacher effectiveness of high and low emotionally intelligent secondary school teachers working in government and private schools with more or less experienced years of experience in Punjab, the data has been analysed using univariate analysis of variance. The mean and standard deviation were calculated for teacher effectiveness score and are presented below in table 1 . 
Table 1

Means of sub-groups of anova for $2 \times 2 \times 2$ design with respect to teacher effectiveness in relation to teaching experience, school type and emotional intelligence

\begin{tabular}{|c|c|c|c|c|c|c|c|c|c|}
\hline ST & EI & TE & \multicolumn{2}{|c|}{$\begin{array}{c}\text { Teacher } \\
\text { Effectiveness }\end{array}$} & \multirow[t]{4}{*}{$\mathbf{S T}$} & Low & \multirow{2}{*}{$\begin{array}{c}\text { TE } \\
\text { Less experienced } \\
\mathrm{N}=63\end{array}$} & \multicolumn{2}{|c|}{$\begin{array}{c}\text { Teacher } \\
\text { Effectiveness }\end{array}$} \\
\hline \multirow{9}{*}{ Govt. } & \multirow{3}{*}{ Low } & $\begin{array}{l}\text { Less experienced } \\
\qquad \mathrm{N}=34\end{array}$ & $\begin{array}{l}M= \\
\sigma=\end{array}$ & $\begin{array}{c}295.91 \\
37.2\end{array}$ & & \multirow{3}{*}{ Low } & & $\begin{array}{l}M= \\
\sigma=\end{array}$ & $\begin{array}{c}301.27 \\
36.2\end{array}$ \\
\hline & & $\begin{array}{l}\text { More experienced } \\
\qquad \mathrm{N}=58\end{array}$ & $\begin{array}{l}M= \\
\sigma=\end{array}$ & $\begin{array}{c}302.43 \\
27.8\end{array}$ & & & $\begin{array}{l}\text { More experienced } \\
\qquad \mathrm{N}=31\end{array}$ & $\begin{array}{l}M= \\
\sigma=\end{array}$ & $\begin{array}{c}313.77 \\
24.9\end{array}$ \\
\hline & & $\begin{array}{c}\text { Total } \\
\mathrm{N}=92\end{array}$ & $\begin{array}{l}M= \\
\sigma=\end{array}$ & $\begin{array}{c}300.02 \\
31.6\end{array}$ & & & $\begin{array}{c}\text { Total } \\
\mathrm{N}=94\end{array}$ & $\begin{array}{l}M= \\
\sigma=\end{array}$ & $\begin{array}{c}305.39 \\
33.3\end{array}$ \\
\hline & & $\begin{array}{l}\text { Less experienced } \\
\qquad \mathrm{N}=23\end{array}$ & $\begin{array}{l}M= \\
\sigma=\end{array}$ & $\begin{array}{c}318.43 \\
35.9\end{array}$ & & & $\begin{array}{l}\text { Less experienced } \\
\qquad N=68\end{array}$ & $\begin{array}{l}M= \\
\sigma=\end{array}$ & $\begin{array}{c}324.72 \\
19.9\end{array}$ \\
\hline & High & $\begin{array}{l}\text { More experienced } \\
\qquad N=66\end{array}$ & $\begin{array}{l}M= \\
\sigma=\end{array}$ & $\begin{array}{c}328.92 \\
31.0\end{array}$ & & High & $\begin{array}{l}\text { More experienced } \\
\qquad \mathrm{N}=30\end{array}$ & $\begin{array}{l}M= \\
\sigma=\end{array}$ & $\begin{array}{c}330.93 \\
15.8\end{array}$ \\
\hline & & $\begin{array}{c}\text { Total } \\
\mathrm{N}=89\end{array}$ & $\begin{array}{l}M= \\
\sigma=\end{array}$ & $\begin{array}{c}326.21 \\
32.5\end{array}$ & & & $\begin{array}{c}\text { Total } \\
\mathrm{N}=98\end{array}$ & $\begin{array}{l}M= \\
\sigma=\end{array}$ & $\begin{array}{c}326.62 \\
18.9\end{array}$ \\
\hline & & $\begin{array}{l}\text { Less experienced } \\
\qquad \mathrm{N}=57\end{array}$ & $\begin{array}{l}M= \\
\sigma=\end{array}$ & $\begin{array}{c}305.00 \\
38.0\end{array}$ & Private & Total & $\begin{array}{l}\text { Less experienced } \\
\qquad \mathrm{N}=131\end{array}$ & $\begin{array}{l}M= \\
\sigma=\end{array}$ & $\begin{array}{c}313.44 \\
31.1\end{array}$ \\
\hline & Total & $\begin{array}{l}\text { More experienced } \\
\qquad \mathrm{N}=124\end{array}$ & $\begin{array}{l}M= \\
\sigma=\end{array}$ & $\begin{array}{c}316.53 \\
32.3\end{array}$ & & & $\begin{array}{l}\text { More experienced } \\
\qquad N=61\end{array}$ & $\begin{array}{l}M= \\
\sigma=\end{array}$ & $\begin{array}{c}322.21 \\
22.5\end{array}$ \\
\hline & & $\begin{array}{c}\text { Total } \\
\mathrm{N}=181\end{array}$ & $\begin{array}{l}M= \\
\sigma=\end{array}$ & $\begin{array}{c}312.90 \\
34.5\end{array}$ & & & $\begin{array}{c}\text { Total } \\
\mathrm{N}=192\end{array}$ & $\begin{array}{l}M= \\
\sigma=\end{array}$ & $\begin{array}{c}316.23 \\
28.9\end{array}$ \\
\hline & & $\begin{array}{l}\text { Less experienced } \\
\qquad \mathrm{N}=97\end{array}$ & $\begin{array}{l}M= \\
\sigma=\end{array}$ & $\begin{array}{c}299.39 \\
36.5\end{array}$ & & & $\begin{array}{l}\text { Less experienced } \\
\qquad \mathrm{N}=91\end{array}$ & $\begin{array}{l}M= \\
\sigma=\end{array}$ & $\begin{array}{c}323.13 \\
24.8\end{array}$ \\
\hline & Low & $\begin{array}{l}\text { More experienced } \\
\qquad \mathrm{N}=89\end{array}$ & $\begin{array}{l}M= \\
\sigma=\end{array}$ & $\begin{array}{c}306.38 \\
27.3\end{array}$ & & & $\begin{array}{l}\text { More experienced } \\
\qquad \mathrm{N}=96\end{array}$ & $\begin{array}{l}M= \\
\sigma=\end{array}$ & $\begin{array}{c}329.55 \\
27.1\end{array}$ \\
\hline Total & & $\begin{array}{c}\text { Total } \\
\mathrm{N}=186\end{array}$ & $\begin{array}{l}M= \\
\sigma=\end{array}$ & $\begin{array}{c}302.74 \\
32.5\end{array}$ & Total & High & $\begin{array}{c}\text { Total } \\
\mathrm{N}=187\end{array}$ & $\begin{array}{l}M= \\
\sigma=\end{array}$ & $\begin{array}{c}326.43 \\
26.2\end{array}$ \\
\hline & & $\begin{array}{l}\text { Less experienced } \\
\qquad \mathrm{N}=188\end{array}$ & $\begin{array}{l}M= \\
\sigma=\end{array}$ & $\begin{array}{c}310.88 \\
33.5\end{array}$ & & & $\begin{array}{l}\text { More experienced } \\
\qquad \mathrm{N}=185\end{array}$ & $\begin{array}{l}M= \\
\sigma=\end{array}$ & $\begin{array}{c}318.41 \\
29.5\end{array}$ \\
\hline & $10 t a$ & $\begin{array}{c}\text { Total } \\
\mathrm{N}=373\end{array}$ & $\begin{array}{l}M= \\
\sigma=\end{array}$ & $\begin{array}{c}314.61 \\
31.7\end{array}$ & & & & & \\
\hline & & ion & li & co & & & & & \\
\hline
\end{tabular}


In order to analyze the variance of teacher effectiveness of high and low emotionally intelligent secondary school teachers working in government and private schools with more than/Less experienced years of experience, the obtained scores were subjected to ANOVA and the results have been presented in the table 2 .

Table 2

Summary of anova for $2 \times 2 \times 2$ design with respect to teacher effectiveness in relation to teaching experience, school type and emotional intelligence

\begin{tabular}{lcccc}
\hline \multicolumn{1}{c}{ Source } & df & Type III SS & MSS & F \\
\hline School Type & 1 & 3101.50 & 3101.50 & 3.60 \\
EI & 1 & 39874.47 & 39874.47 & 46.29 \\
TE & 1 & 6335.64 & 6335.64 & 7.36 \\
$\mathbf{S T} \times$ EI & 1 & 350.78 & 350.78 & 0.41 \\
$\mathbf{S T} \times \mathbf{T E}$ & 1 & 14.49 & 14.49 & 0.02 \\
$\mathbf{E I} \times \mathbf{T E}$ & 1 & 26.75 & 26.75 & 0.03 \\
$\mathbf{S T} \times \mathbf{E I} \times \mathbf{T E}$ & 1 & 522.72 & 522.72 & 0.61 \\
Error & 365 & 314426.62 & 861.44 & \\
Total & 373 & 37300000 & & \\
\hline
\end{tabular}

\section{Main Effects}

\section{School Type}

It has been observed from table 2, that F-ratio for the differences in school type for teacher effectiveness score is found to be 3.6. Thus, the value for difference between the means of Teacher effectiveness score of secondary school teachers working in government and private schools teachers is found to be insignificant at 0.05 level. This indicates that two groups of government and private secondary school teachers do not differ significantly on their scores of Teacher effectiveness. Thus, the results do support hypothesis (1), “There is no significant difference between teacher effectiveness of teachers serving in government and private secondary schools". 
Meaning thereby, that the type of institution i.e. government and private do not influence or contribute to the effectiveness of teachers. The results are in tune with the findings of Singh (2012); Singh (2012).

\section{Emotional Intelligence}

It has been observed from table 2, that F-ratio for the differences in Teacher effectiveness score is found to be 46.29 . The critical value is found to be significant at 0.01 level. This indicates that two groups of secondary school teachers with high and low emotional intelligence differ significantly on their scores of Teacher effectiveness. Thus, the results reject the hypothesis (2), "There is no significant difference between teacher effectiveness of secondary school teachers with high and low emotional intelligence". From reviewing the corresponding means in table 1, it is found that teachers with low emotional intelligence (302.74) had scored less on Teacher effectiveness than teachers with high emotional intelligence (326.43). Meaning thereby, teachers with high emotional intelligence are more effective in their teaching than teachers with low emotional intelligence. The results are in tune with the studies conducted by Cirarrochi, Chan and Caputi (2000); Sutton and Whitely (2003) and Kauts and Saroj (2010).

\section{Teaching Experience}

It has been observed from table 2, that F-ratio for the differences in teaching experience for Teacher effectiveness score is found to be 7.36. Thus, the value for difference between the means of Teacher effectiveness score of secondary school teachers with teaching experience less than and More experienced years of experience is found to be significant at 0.01 level. This indicates that two groups of secondary school teachers with more or less 10 years of teaching experience differ significantly on their scores of Teacher effectiveness. Thus, the results reject the hypothesis (3), "There is no significant difference between teacher effectiveness of secondary school teachers with 
more/Less experienced years of teaching experience”. From reviewing the corresponding means in table 1 , it is found that teachers with more experienced years of teaching experience (318.41) had scored more on Teacher effectiveness than teachers with Less experienced years of teaching experience (310.88). From this, it can be interpreted that experience is a factor contributing to teaching effectiveness. More experienced teachers in general will be more effective than teachers with less experience of teaching. The results are in tune with the findings of Kane et al (2006); Rivkin et al. (2005); Decker, et al (2004), which states that with experience teachers become more effective. Ling (2008) and Basiron (1999) also reported that experienced teachers are comfortable in handling extra-curricular activities and sports activities.

\section{Two Order Interaction}

It has been observed from table 2, that F-ratio for the interaction between school type and emotional intelligence, school type and teaching experience, and emotional intelligence and teaching experience for Teacher effectiveness is found to be 0.41 . Thus, the value for the interaction between school type and emotional intelligence, school type and teaching experience, and emotional intelligence and teaching experience of Teacher effectiveness of secondary school teachers is found to be insignificant at 0.05 level. This indicates that perception of secondary school teachers on the scores of Teacher effectiveness as a result of interaction of school type and emotional intelligence, school type and teaching experience, and emotional intelligence and teaching experience for different sub groups do not differ significantly. Thus, the results do support hypothesis (4), “There is no interaction effect of school type and emotional intelligence, school type and teaching experience, and emotional intelligence and teaching experience on the scores of Teacher effectiveness of secondary school teachers". This interpret to that together the variable of 
emotional intelligence and school type, school type and teaching experience, and emotional intelligence and teaching experience are not able to influence teaching effectiveness of teachers.

\section{Three Order Interaction}

It has been observed from table 2, that F-ratio for the interaction between school type, emotional intelligence and teaching experience for Teacher effectiveness is found to be 0.61 . Thus, the value for the interaction between school type, emotional intelligence and teaching experience of Teacher effectiveness of secondary school teachers is found to be insignificant at 0.05 level. This indicates that perception of secondary school teachers on the scores of Teacher effectiveness as a result of interaction of school type, emotional intelligence and teaching experience for different sub groups do not differ significantly. Thus, the results do support hypothesis (5), "There is no interaction effect of school type, emotional intelligence and teaching experience on the scores of Teacher effectiveness of secondary school teachers". This interprets to that together the variable of emotional intelligence, school type, and teaching experience is not able to influence teaching effectiveness of teachers.

\section{Discussion on Findings}

The purpose of the present study is to find the differences existing between teacher effectiveness of groups based on emotional intelligence, school type and teaching experience and their interaction effects. However, the differences in teacher effectiveness of groups of teachers' based on school type i.e. government and private secondary schools, are not significant. This finding is in tune with the findings of Singh (2012) and Singh (2012) who reported that teachers working in government and private schools are equally effective in teaching. Second, important finding evolved through the study is that the secondary school teachers with high and low emotional intelligence differ significantly on their teaching effectiveness. And, teachers with low emotional 
intelligence are less effective in teaching than teachers with high emotional intelligence. Similar to the finding, different studies conducted by Cirarrochi, Chan and Caputi (2000); Sutton and Whitely (2003) and Kauts and Saroj (2010) concluded that emotional intelligence is a key factor in the success in teaching and to become more effective, one needs to be more emotionally intelligent. Also, teacher effectiveness of less and more experienced secondary school teachers is found significant. More experienced teachers are found to be more effective than less experienced teachers. Similar results were reported by Kane et al (2006); Rivkin et al. (2005); Decker, et al. (2004); Ling (2008) and Basiron (1999) which states that with experience teachers become more effective in dealing with different types of teacher responsibilities.

Thus, it can be concluded that emotional intelligence and teaching experience matters in making of a teacher to be effective. Thus the emotional intelligence training which does not have any place in the training of pre service and in service trainings shall be made the part of orientation and refresher courses. The researches have proved that emotional intelligence can be developed. For the fresh recruitments the testing of emotional intelligence can be included alongwith the certification. Similarly, the teaching experience makes a point for the administrators that more challenging and difficult tasks \& responsibilities shall be given to more experienced teachers. Both the findings are very important for policy makers and administrators at the grassroot level of school functioning and upright at the recruitment policy by planners.

\section{References}

Salamuddin, N., Harun, M. T. \& Abdullah, N. A. D. (2011). Teachers' Competency in School Extra-Curricular Management, World Applied Sciences Journal, 15 (Innovation and Pedagogy for Lifelong Learning), 49-55. 
Blatchford, P., Moriarty, V., Edmonds, S., \& Martin, C. (2002). Relationships between class size and teaching: A multi method analysis of English infant schools. American Educational Research Journal, 39 (1). 101-32. EJ649893.

Carnegie Forum on Education and the Economy. (1986). A Nation Prepared: Teachers for the 21st Century. New York: Carnegie Forum.

Caruso, D., Mayer, J. D., \& Salovey, P. (2002). Relation of an ability measure of emotional intelligence to personality. Journal of Personality Assessment, 79, 306-320.

Chan, D. W. (2008). Emotional intelligence, self-efficacy, and coping among chinese prospective and in-service teachers in Hong Kong (EJ799375). Educational Psychology, 28 (4). 397-408.

Clotfelter, C. T., Ladd, H. F. \& Vigdor, J. L. (2007b). Teacher Credentials and Student Achievement in High School: A Cross-Subject Analysis with Student Fixed Effects (CALDER Working Paper 11). Washington, DC: The Urban Institute.

Clotfelter, C. T., Ladd, H. F. \& Vigdor, J. L. (2007a). How and Why Do Teacher Credentials Matter for Student Achievement? (CALDER Working Paper 2). Washington, DC: The Urban Institute.

Conley, S. \& Cooper, B. (1991). The School as a Work Environment: Implications for Reform. Boston: Allyn and Bacon.

Cross, C. T., \& Rigden, D. W. (2002). Improving teacher quality. American School Board Journal, 189 (4). 24-272. http://eric.ed.gov/?id=EJ642952.

Darling-Hammond, L. (1984). Beyond the Commission Reports: The Coming Crisis in Teaching. Santa Monica, CA: Rand Corporation. 
Darling-Hammond, L. (1995). The Current Status of Teaching and Teacher Development in the United States. Paper prepared for the National Commission on Teaching and America's Future.

Decker, P. T., Mayer, D. P., \& Glazerman, S. (2004). The effects of Teach For America on students: Findings from a national evaluation. Washington, DC: Mathematica. Retrieved from http://www.teachforamerica.org/documents/mathematica.results_6.9.04.pdf.

Harris, D. N. \& Sass, T. R.. 2007. Teacher Training, Teacher Quality, and Student Achievement (CALDER Working Paper 3). Washington, DC: The Urban Institute.

Holmes Group. (1986). Tomorrow's Teachers. East Lansing, MI: Holmes Group.

Kalita, A. (2012). A study on managing effectiveness of secondary school teachers in Guwahati city, India. The Clarion, 1 (2), 238-241.

Kane, T. J., Rockoff, J. E. \& Staiger, D. O. (2006). What Does Certification Tell Us about Teacher Effectiveness? Evidence from New York City (Working Paper 12155). Cambridge, MA: National Bureau of Economic Research.

Kauts, A., \& Saroj, R (2010). Study of teacher effectiveness and occupational stress in relation to emotional intelligence among teachers at secondary stage. Journal of History and Social Sciences, 1(1). Retrieved from http://jhss.org/archivearticleview.php?artid=85.

Ladd, H. F. (Eds.). (2008). Proceedings from second annual CALDER research conference’ 2008: The Ins and Outs of Value-Added Measures in Education: What Research Says. Washington, D.C.: The Urban Institute. Retrieved from http://www. caldercenter.org/upload/Sunny_Ladd_presentation.pdf. 
Manu, V. \& Yellappa, P. (2013). Teaching effectiveness of secondary school teachers in relation to their teaching aptitude. Research Analysis and Evaluation (International Referred Research Journal), April-May (Combined), 4 (43-44).

Mayer, J. D., Salovey, P., \& Caruso, D. (2004b). Emotional intelligence: Theory, findings and implications. Psychological Inquiry, 15(3), 197-215.

National Council of Educational Research and Training. (1970). Education and National Development (Report of the Education Commission, 1964-66, Vol 3: Higher Education). New Delhi: NCERT.http://www.teindia.nic.in/files/reports/ccr/kc. pdf

Onderi, H. \& Croll, P. (2009). Teacher self-perceptions of effectiveness: a study in a district of Kenya. Educational Research, 51 (1), 97-107. http://web.ebscohost.com (37195163).

Reynolds, A., Reagin, M., \& Reinshuttle, K. (2001). Less is more: What teachers say about decreasing class size and increasing learning. American School Board Journal, 188 (9), 3032. http://eric.ed.gov/?id=EJ632483.

Rivkin, S. G., Hanushek, E. A., \& Kain, J. F. (2005). Teachers, schools, and academic achievement. Econometrica, 73(2), 417-458.

Rosenholtz, S. (1989). Teacher's Workplace: The Social Organization of Schools. New York: Longman.

Sergiovanni, T.J. \& Moore, J. (1989). Schooling for Tomorrow. Boston: Allyn and Bacon.

Singh, P. R. (2012). Study of Effectiveness of Secondary School Teachers. Shodh, Samiksha Aur Mulyankan (International Referred Research Journal), 4 (42).

Singh, Y. G. (2012). Teacher's effectiveness in relation to Their some Variables. Shodh, Samiksha Aur Mulyankan (International Referred Research Journal), 3 (37). 
Sutton, R. E \& Whitely, K.F. (2003). Teachers Emotions and Teaching: a Review of the Literature and Directions for Future Research. Educational Psychology Review, 5 (4), 327-358.

Talbert, J. \& McLaughlin, M. (1993). Teacher Professionalism in Local School Contexts. American Journal of Education, 102, 123-153.

Weis, L., Altbach, P., Kelly, G., Petrie, H., \& Slaughter, S. (1989). Crisis in Teaching. Albany, NY: State University of New York Press. 